\title{
This Shy Caribbean Lizard is Now a Coveted Pet-and Critically Endangered. How Did This Happen?
}

Poachers have used scientific reports as maps to track down and catch the lizard. It's not the only one.

\author{
Dina Fine Maron \\ National Geographic Society, Washington, D.C. 20036 \\ Photographs by Jeremy Holden, Fauna \& Flora International.
}

$\mathrm{F}$ ather Mark de Silva greeted the two American herpetologists at an airstrip on Union Island, one of more than 30 specks of land in the Caribbean that make up the country of Saint Vincent and the Grenadines. It was a June day in 2005, and they'd come to see a gecko.

Not any old gecko. Months earlier when the Catholic priest and avid nature observer was studying plant life on the island, he came upon a creature he'd never seen before. It was a tiny lizard, about two and a half inches long from snout to tail, covered with bull's-eye patterns of red and black with white centers.

de Silva snapped a photo and asked around if anyone recognized the animal. No one did.

Then the herpetologists got involved. Robert Powell, a biology professor at Avila University, in Kansas City, Missouri, and Robert Henderson, a vertebrate zoology expert with the Milwaukee Public Museum, in Wisconsin, had traveled to Saint Vincent and the Grenadines to lay the groundwork for an upcoming student trip. When officials in the country's forestry department mentioned de Silva's find, the scientists were intrigued and hopped the short flight to Union Island in the hope of encountering the gecko.

de Silva agreed to show the way, and together the group drove to the lush forest overlooking Chatham Bay, where they retraced his steps. It wasn't long before Henderson spotted not one but two of the geckos. "We were quite pleased," Powell remembers in the understated language of scientists.

They asked de Silva to co-author a scientific paper describing the discovery - or at least to let them name the gecko after him-but he demurred, Powell says. So, in December 2005, they published a scientific paper about the

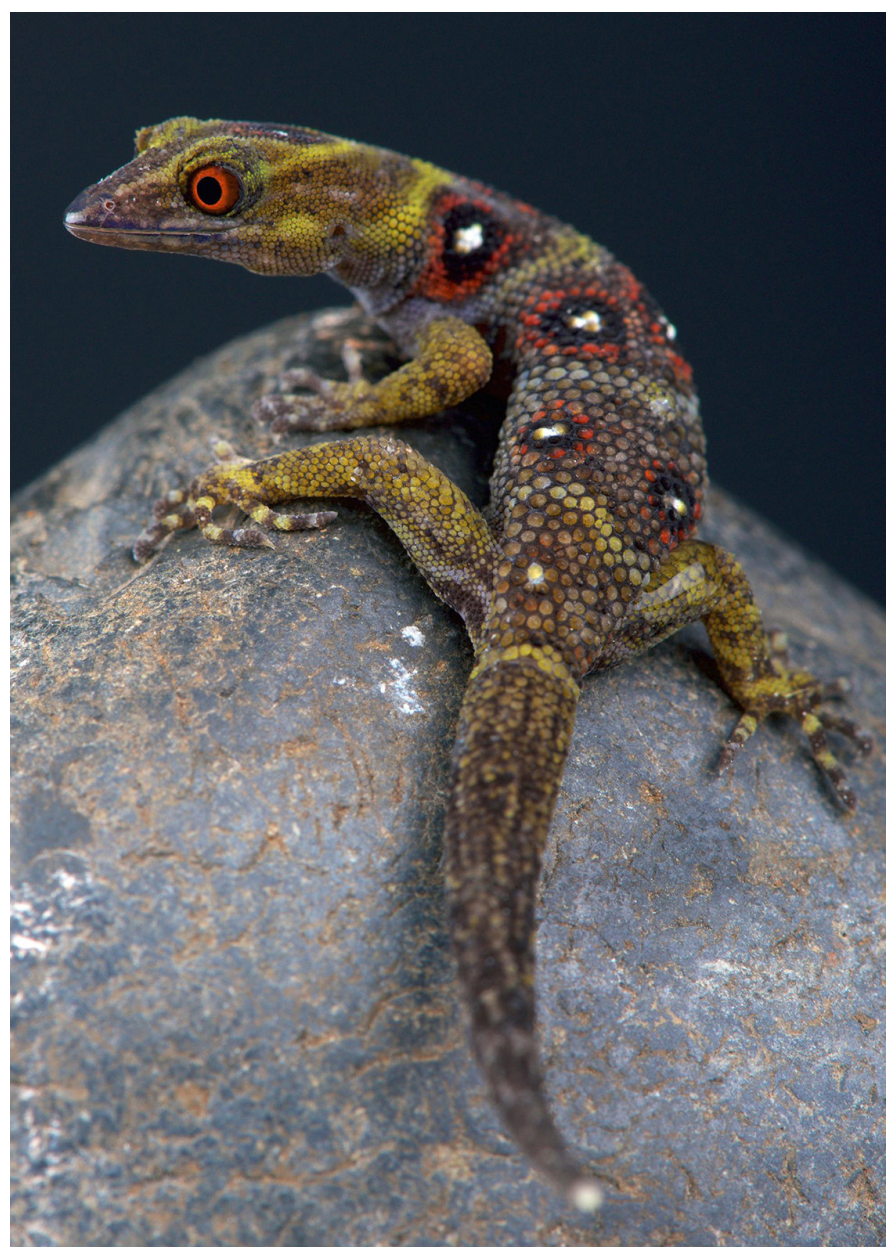

The Union Island Gecko (Gonatodes daudini) was revealed as new to science in 2005. Poachers have since smuggled so many of the tiny lizards from Saint Vincent and the Grenadines for the exotic pet industry that they now may number no more than 10,000 . 
discovery of the Union Island Gecko (Gonatodes daudini), also known as the Grenadines Clawed Gecko. They included a note at the end crediting de Silva as the discoverer.

What Powell and Henderson didn't anticipate was how their paper, and subsequent detailed descriptions of the Union Island gecko's location, would serve as a treasure map for lizard collectors. "When you put this gecko in its natural habitat - a rock crevice or cave or leaf litter-that tends to break up its outline, so rather than being a bright signal, its coloring makes it harder to see," Powell says. "It serves a biological purpose, but unfortunately it's attractive enough that it's appealing to pet connoisseurs."

Under the Saint Vincent and the Grenadines Wildlife Protection Act of 1987, it's illegal to remove the geckos (or any other wildlife) without written permission. But such is the insatiable appetite for new and exotic pets that collectors learning of the discovery soon descended on the island in search of the tiny reptiles. They smuggled out so many of them that in 2011 the International Union for the Conservation of Nature (IUCN), the body that sets the conservation status of wildlife, categorized the Union Island gecko as critically endangered.

But poachers kept coming. Between 2010 and 2018 the density of the geckos in much of their described range shrank by roughly 80 percent, says Jenny Daltry, a senior conservation biologist and head of the Caribbean office for the nonprofit Fauna \& Flora International. "It's surprising how quickly their numbers have dropped. You hear a lot about lions and tigers but not the sheer number of reptiles being traded," she says.

It's possible, she says, that no more than 10,000 of the geckos now remain on Union Island. Extensive searches in the region by Powell and his team have revealed no geckos outside their forest home above Chatham Bay, an area no bigger than about two city blocks. If that patch of forest is destroyed, the geckos could go extinct. "We hold out hope that there may be others elsewhere, but despite our best efforts we have not found them," he says.

Chris Shepherd, executive director of Monitor, an organization in British Columbia, Canada, dedicated to combating illegal wildlife trade, says demand for pet geckos appears to be on the rise. The animals are particularly popular, he says, because they're so small and relatively easy to smuggle.

Recently, Shepherd has found that Union Island geckos are showing up in a variety of European markets, sold as prized pets. He and his colleagues note that at least 36 were advertised online during the past four years. They were listed most often in Germany, the Netherlands, and Austria. Five of the animals were explicitly billed as coming from the wild.

Although those numbers may seem insignificant, Shepherd notes that the wild population is quite small and confined to a single area, so each removal could "deal a devastating blow to the long-term survival of the population."

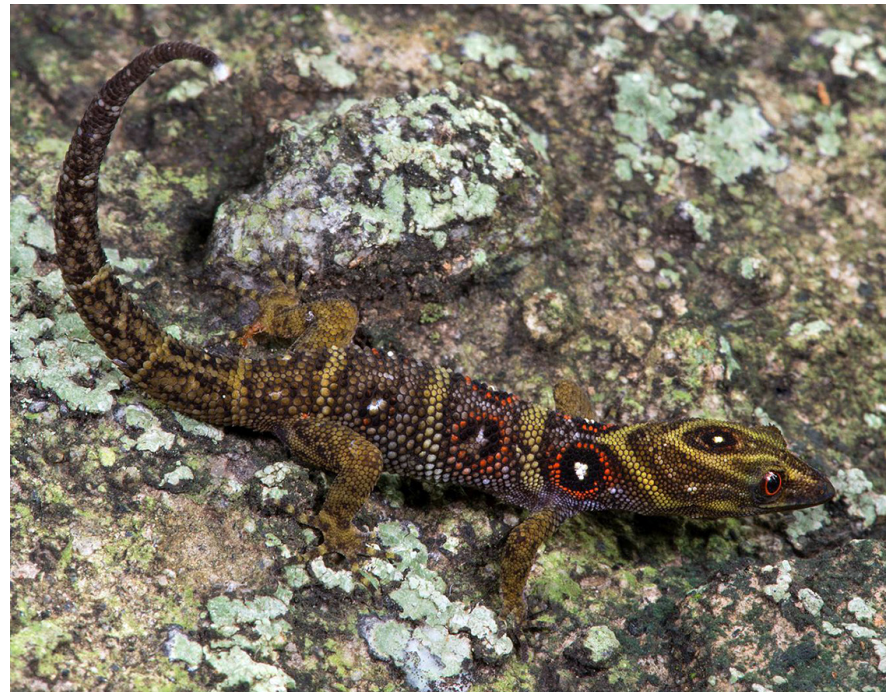

The geckos live only in a tiny patch of forest on Union Island, where Fauna \& Flora International is working closely with the St. Vincent \& the Grenadines Forestry Department and the Union Island Environmental Attackers to safeguard the future for these diminutive lizards. Local warden patrols and motion sensor cameras have been set up to help protect the critically endangered species.

Also, he says, "it's not known what damage and disruption to the habitat was done when the animals were collected." Getting a full picture of the illegal trade remains impossible, he adds. "For all we know," those 36 ads "could be the tip of the iceberg."

\section{Not the Only Casualty of Discovery}

With poachers scouring scientific literature for new animals to exploit for the pet industry, the plight of the Union Island gecko is a familiar one.

The Roti Island Snake-necked Turtle (Chelodina mccordi), for example, became critically endangered after it was identified as a unique species in Indonesia and described in a journal in 1994. As the IUCN noted in its listing for the turtle, "populations were decimated within five years and the species is now considered commercially and ecologically extinct on Roti."

Similarly, the Earless Monitor Lizard (Lanthanotus borneensis), found only in Borneo, was first described in 2012 in a paper in the Journal of Threatened Taxa. The authors purposely were vague about the lizard's location, writing that because of "the species' rareness and its high conservation value, it cannot be ruled out that pet reptile collectors and traders may misuse this additional information." Although they omitted specific geographic coordinates, the details they provided were useful enough for the most dogged collectors, and soon the animals were being sold in international markets. (The earless monitor lizard's numbers haven't yet been formally assessed by the IUCN.) 
This dire consequence of the scientific process isn't limited to reptiles. As the discoverers of a rare orchid that grows only in one part of Borneo noted in 2011, although the plant was being sold before they formally described it, the very fact of its documentation will make it a target for commercial collecting. They wrote: "We are presented with a moral issue as taxonomists; describing a new, possibly critically endangered species will increase its commercial value and will further endanger the population."

The year before, a Vietnamese orchid, Paphiopedilum canhii, had been all but wiped out by commercial collectors who removed 99 percent of the plants shortly after its discovery. The rush was driven by the publication of its image on the Internet, by an article in a trade magazine, and by its description in a scientific journal.

These days, Powell says, researchers rarely list the precise coordinates of plants and animals.

Some journals are also taking the initiative to mitigate the poaching problem. Zhi-Qiang Zhang, chief editor of Zootaxa, for example, describes a policy the journal put in place to safeguard newly discovered species. Scientists may list the location of a species at the county or city level but must not give details of the exact habitats or sites, he says. "For species with sensitive status, such as Union Island geckos, we allow editors to make [a] decision about the details required for publication. We also allow authors to make a statement that [they] can provide detailed info about the site to genuine researchers when they request these in writing," Zhang wrote in an email.

\section{Protecting the Geckos}

To help protect Union Island geckos, the government of Saint Vincent and the Grenadines is working with environmental groups such as Fauna \& Flora International to set up remote surveillance equipment, including camera traps, and oversee local patrols in the area around the animal's habitat.

Wardens patrol the area daily and community groups have also begun tours for tourists to raise awareness about the threats of poaching and development, as well as to highlight the importance of preserving the gecko's forest habitat.
Lizard advocates also hope the 182 countries and the European Union that are the signatories to the treaty that regulates cross-border trade of wildlife-the Convention on International Trade in Endangered Species of Wild Fauna and Flora (CITES) — will vote at their upcoming meeting to ban any international trade of the Union Island gecko. Separately, the Roti Island snake-necked turtle is also under consideration for the strictest level of protection at the meeting, which was to be held in Sri Lanka but has been postponed because of the terrorist attacks there.

Even though it's illegal under Saint Vincent and the Grenadines law to export the geckos, little can be done to stop the global trade unless the animal is listed under CITES, says Rebecca Drury, Fauna \& Flora International's head of wildlife trade and a National Geographic explorer. A CITES trade ban would mean that officials in the EU and elsewhere would have legal grounds to confiscate smuggled geckos.

Meanwhile, the little lizard has become something of a darling for the islanders. "They're quite proud of the geckos," Drury says, adding that "they're now featured locally on postcards and on t-shirts sold to tourists."

Reflecting on his team's original decision to publish the details of the Union Island Gecko's habitat, Powell says, "If we had to do it over again, we wouldn't have been as precise in describing the location. I don't think we could have described the species without saying it was on Union Island, but we would not have narrowed it down as precisely as we did."

Still, he adds, "realistically speaking there are many people on Union that know this is the best patch of intact forest, so someone coming to the island and asking around would be quickly directed to that site. That's a conundrum."

Wildlife Watch is an investigative reporting project between National Geographic Society and National Geographic Partners focusing on wildlife crime and exploitation. Copyright (C) 2019 National Geographic Partners, LLC. All rights reserved. Originally published on 30 April 2019 at https://www.nationalgeographic.com/animals/2019/04/union-islandgecko-poached-for-pet-trade/. Reprinted and adapted with permission. Changes involve adaptation to R\&A format and the insertion of scientific names. 